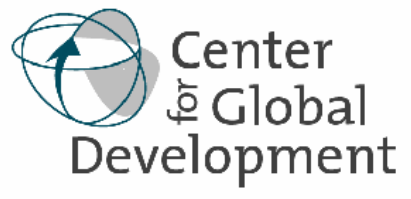

Working Paper Number 46 September 2004

\author{
Beyond HIPC: Secure Sustainable Debt Relief for Poor Countries \\ By Nancy Birdsall and Brian Deese
}

Abstract
In 1999, the United States and other major donor countries supported an historic expansion of the heavily
indebted poor country (HIPC) debt relief initiative. HIPC had two primary goals: reduce poor countries' debt
burdens to levels that would allow them to achieve sustainable growth; and promote a new way of assisting
poor countries focused on home-grown poverty alleviation and human development. Three years after the
initiative came into existence, we are beginning to see the apparent impact that HIPC is having, particularly
on recipient countries' ability and willingness to increase domestic spending on education and HIVIAIDS
programs. Yet it has also become clear that the HIPC program is not providing a sufficient level of
predictability or sustainability to allow debtor countries (and donors) to reap the larger benefits, particularly
in terms of sustained growth and poverty reduction, originally envisioned. An adequate amount of
predictable debt relief can be an extremely efficient way of transferring resources to poor countries with
reasonable economic management (indeed, more effective than traditional aid). But the full benefits of the
transfer, in improved capacity to manage their economies, and in increased investor confidence in an
economy's future, require that creditors, investors and committed recipient government officials have
confidence that the improved debt situation will be sustained over the medium term. After reviewing some
of the main critiques and proposals for change, we offer here a new way forward -- a proposal to deepen,
widen, and most importantly insure debt relief to poor countries. We focus on the insurance aspect of our
proposal, that would safeguard countries against external shocks for a decade, and on the advantages of
financing such insurance by limited mobilization of IMF gold. We see this proposal as a practical way to
make debt relief more predictably sustainable in HIPC countries, and a proposal around which international
donors could consolidate their efforts in the near term. 


\title{
Beyond HIPC: Secure Sustainable Debt Relief for Poor Countries*
}

\author{
By Nancy Birdsall and Brian Deese ${ }^{1}$
}

August 15, 2002

\section{$\underline{\text { Introduction }}$}

Jubilee 2000 - a worldwide citizens’ movement supported by the pop star Bono, Pope John Paul II, and millions of ordinary churchgoing people the United States and Europe - was the most successful developed-country movement aimed at combating world poverty for many years, perhaps in all recorded history. It succeeded not just in changing official policy, but in arousing an unusual measure of concern among the world's rich about the state of the world's poor. Jubilee campaigners argued convincingly that the debts owed by poor countries to rich institutions like the IMF and World Bank and to the governments of industrial countries were an unjust burden on their citizens, who were paying obligations mostly assumed by corrupt past leaders. And this debt was sabotaging the ability of even the most reformist, well-intentioned governments to provide minimal social services to their citizens. Jubilee's success was embodied the Enhanced Heavily Indebted Poor Country (HIPC) initiative, agreed to by all the major donors in $1999 .{ }^{2}$

While the political momentum behind the initiative was new, the 1999 agreement represented only one more step - a big one, admittedly - in more than a decade of international negotiations aimed at reducing the debt burden of the poorest countries of the world (Box 1 catalogues this history).

For the donors, HIPC was not just good politics. Donor countries had another reason to swallow hard, organize, and cancel some of the debt owed to them by the world's poorest countries. Two decades of official lending at cheap rates had failed to catalyze the increased growth and new economic activities needed to finance the resulting debt. Donors had therefore gotten locked into "defensive lending." Unwilling to let poor countries explicitly default, especially to the multilateral creditors, they were stuck with endless rounds of rescheduling debt and negotiating new grants and loans to help poor countries pay back old loans, sometimes independent of recipient countries' ability to use any external resources well. ${ }^{3}$

\footnotetext{
* This paper builds upon and expands the ideas presented in Delivering on Debt Relief: From IMF Gold to a New Aid Architecture, by Nancy Birdsall and John Williamson, with Brian Deese (Institute for International Economics/Center for Global Development, 2002).

${ }^{1}$ Nancy Birdsall (nbirdsall@cgdev.org) is President, and Brian Deese (bdeese@cgdev.org) is a researcher at the Center for Global Development.

${ }^{2}$ As background to the concerns raised by Jubilee 2000 and the debt relief issue more generally, we present an appendix of ten commonly asked questions and their answers.

${ }^{3}$ Birdsall, Claessens and Diwan (2000) show that in a subgroup African countries with unusually high multilateral debt as a share of total debt, the donors collectively (with the important exception of IDA) appear to have channeled resources independently of country capability.
} 
Debt relief seemed to hold out the promise of getting both the donors and the debtors back on track. Since 1999, the more than $\$ 1.3$ billion released annually in the 26 countries already approved for debt relief has had some apparent impact. ${ }^{4}$ But it has also become clear that the current program is not providing a sufficient level of predictability or sustainability to allow debtor countries (and donors) to reap the full benefits originally envisioned. Many countries will continue to have unsustainable levels of debt after HIPC, owed particularly to multilateral donors like the World Bank and IMF.

We begin this paper by presenting an analytical argument why debt relief can be a more efficient resource transfer than just more new aid. We then turn to the current HIPC framework, and review some of the main critiques and proposals for change. Building on the critiques and proposals, we conclude by offering a new way forward -- a three-pronged proposal to deepen, widen, and insure debt relief to poor countries. We focus on the third of these proposals, as the most critical and practically feasible debt relief reform around which international donors could consolidate their efforts in the near term.

\section{Debt relief is effective aid}

Debt relief can be more efficient than traditional aid, particularly in countries with a record of responsible government and reasonable respect for the rule of law. Why?

\section{Debt relief helps correct traditional bad habits of the international donors.}

Debt relief cannot be tied to wasteful donor practices - Aid is said to be "tied" when recipient countries are required to purchase goods or services from donor country contractors and suppliers. The practice is highly inefficient, reducing the value of aid by an estimated 15 to 30 percent. $^{5}$ Donors pledged, in the spring of 2000, to end the practice, but exempted food aid and technical assistance from that decision. Technical assistance (mostly consultant advice and training) makes up as much as 25 percent of total development assistance. In a country like Mozambique, U.S. or German consultants funded by the U.S. or Germany can cost 10 to 20 times as much as their competitors from Brazil or South Africa. Assuming that poor countries could get only twice (not 10 times) as much value for each dollar spent in a competitive world market for technical assistance, and adding to that the cost of continuing to tie food aid, we estimate that donors will continue to waste some $\$ 7$ billion per year in aid resources, even after the OECD countries have implemented their pledge.

In contrast to new aid disbursements, which may be inefficiently "tied,” debt relief comes in the form of direct budget support to developing country governments.

\footnotetext{
${ }^{4}$ The World Bank has been able to track an increase in social expenditures in these countries of nearly the same amount (some countries used external debt relief to write down domestic debts). About 40 percent of the debt savings are being directed to education and 25 percent to health care. Nearly every HIPC is using a portion of debt relief to create or expand HIV/AIDS prevention and education programs. Tanzania ended fees for grade school, and Benin ended fees in rural areas - giving millions of children the chance to go to school. Honduras will offer three more years of free schooling, so that public school students can go up to the ninth grade. Uganda has put every child in grade school, and will hire more teachers and pay for more classrooms and textbooks. Mali, Mozambique and Senegal will increase spending on HIV/AIDS prevention, to slow the spread of the pandemic.

${ }^{5}$ Estimate is from Chinnock, Jeffery. (1998) “In Whose Benefit? The Case for Untying Aid.” ActionAid.
} 
Debt relief liberates donors from inefficient 'defensive lending'-Research shows that aid works better in countries where governments are responsible and pursuing sensible economic policies. But in the 1990s, donor behavior was characterized by defensive lending - transferring more resources to those countries with the highest debt, regardless of how well they were performing. This behavior was, in a peculiar sense, well-intentioned. Donors wanted to avoid the negative multiplier effects on poor countries of falling into arrears with multilateral creditors. But it nonetheless created a debt trap for donors as well as recipients, and made aid less effective.

With sufficient debt reduction for the poorest countries, donors would be freed to make sound policies and institutions the sole basis for future decisions on where to spend.

\section{Debt relief allows for poor country ownership of development strategies.}

Debt relief reduces the huge transaction costs of conventional foreign aid programs. Acquiring and managing aid has high transaction costs for recipient countries. Talented government officials in aid-dependent countries must meet daily with local and visiting missions of the World Bank, the IMF, the European Union, UNDP, USAID, and other bilateral aid agencies, as well as with representatives of nongovernmental organizations. All of these aid institutions have different, even competing approaches to health, environment, or financial sector reform, and each has different procurement, disbursement, and monitoring rules and customs. In contrast, debt relief has the peculiar advantage of being like cash-it comes without significant transaction costs. This allows recipient countries to streamline the management of aid resources and, with greater control and ownership over their use, it makes them fully accountable for results.

Debt relief provides flexible budget support and makes governments accountable to citizens. Tanzania received about $\$ 700$ million in new donor funding in 1999, and owed \$230 million that year in debt payments, resulting in a net inflow of aid. But most of the new aid money was linked to specific projects or priorities favored by donors, so the Tanzanian government had to set aside $\$ 230$ million of its limited tax revenues for debt repayment. (Typical HIPC countries spent (before debt relief) about 25 percent of tax revenue to repay existing debts.) Donors prefer supporting projects to providing cash for budget support because project outputs can be monitored and measured, and projects often provide contracts for donor country consultants and suppliers. So even when countries have positive net transfers of aid (new aid minus payments on old debt), their ability to direct resources where it might be most effective is limited.

Debt reduction allows governments to spend precious tax revenue on their own budget priorities, instead of on debt repayments. This makes governments more accountable to their citizens. A shift of some aid resources from new projects to debt relief would give a boost to countries struggling to strengthen honest and democratic governance.

\section{Debt Relief Can Foster Private Investment}

A large amount of debt, and perpetual dependence on the beneficence of donors, creates uncertainty about a government's finances and its ability to deliver macroeconomic stability. Investors worry about heavy future tax burdens imposed to sustain or write down public debt. 
Entrepreneurial energy is directed into less risky projects promising quicker returns - such as retailing, small construction, and marketing - rather than into major new businesses. Debt reduction that is irreversible and provides a reasonable guarantee of debt sustainability can restore investor confidence.

\section{Critique of the HIPC initiative}

The compelling case for debt relief per se has not isolated the enhanced HIPC initiative from criticism. ${ }^{6}$ Its design and implementation have been closely scrutinized, due in large part to the success of the Jubilee movement in broadcasting the promise of debt relief as an alternative mechanism to change the development assistance business for the better.

The many critiques can be put into two broad categories, representing two different perspectives on the underlying causes of the failure of development assistance programs in the poorest countries:

- The "foreign aid down the rathole" camp. ${ }^{7}$ These critics argue that debt relief and other forms of aid have been too great and too easy to get. Recipient governments are often wasteful and corrupt. Even in the best cases of reasonably adequate governance, aid and debt relief simply relieve countries' immediate budget constraint, allowing them to persist with bad economic policies. The official donors and creditors share some blame for providing too many loans, driven by a combination of political, commercial, and bureaucratic motives.

For these critics, enhanced HIPC retains some traditional conditionality. The IMF must still give the nod that macro policies are adequate for a country to reach the first step in the process, the decision point. And the new Poverty Reduction Strategy Papers (PRSP), announced in 1999 were meant to address deeper concerns about poor governance and over-eager donors. The PRSP envisaged a process whereby governments (aided by World Bank staff) would convene extensive consultations with civil society and non-governmental actors, and prepare holistic, country-owned strategies that would form the basis for both HIPC and future donor assistance.

But the requirements for the PRSP process have themselves provoked a fair amount of cynicism. For critics of aid they seem no different from business as susal - in which much that is written and agreed is never implemented. ${ }^{8}$ Another complaint - this time from friends of greater aid not just foes - is that in some countries parliaments have been largely by-passed in the process of popular consultation. ${ }^{9}$ Concern has also been raised that the emphasis on poverty reduction via

\footnotetext{
${ }^{6}$ Among the many critiques are Birdsall and Deese 2002, Eurodad 2001a, Roodman 2001, Oxfam 2001, Drop the Debt 2001, and Jubilee Plus 2001.

7 This argument is represented by Easterly (2000), Thomas (2001) and in some measure by Burnside and Dollar (2000).

${ }^{8}$ Many recalled that (for example) Letters of Intent to the IMF and Letters of Development Policy to the World Bank are also supposed to be documents produced by the borrowing government, but that in practice they have long been written by IMF and World Bank staffers and presented to the would-be borrowing government to sign.

${ }^{9}$ Unfortunately, there is an inherent tension between the focus on participation and the connection between the PRSP and release of HIPC debt relief proceeds, the second representing a form of donor-mandated conditionality that hinders the first. While few argue that increased spending on education and health is a bad idea, many southern NGO and civil society advocates caution not to confuse the pre-set goals of the PRSP process with country ownership. In May 2001,
} 
increases in social expenditures is primarily a donor-owned view, and would not necessarily be the optimal path for a country to attain sustainable growth and thus sustainable reductions in poverty. ${ }^{10}$

A final -- and critically important -- critique is that the PRSPs are not adequately addressing the task of monitoring, and that even if countries buy into the new donor conditionality, it will be impossible to tell where the proceeds of debt relief are really going. The IMF (2001) found that only 2 of the HIPC countries will have the capacity to track spending related to debt relief transactions within the next year.

- The "poverty trap" camp. ${ }^{11}$ Under this argument, debt reduction is too small and tied to conditionality that is onerous and misguided. Given the complex challenges that many poor countries face - conflict, ethnic fragmentation dependence on primary commodities with declining and unstable prices, tropical disease, and often small size -- debt relief and other forms of aid have been far from adequate to allow them to escape poverty and put them onto a growth path. In this perspective, much more of the blame goes to creditors and donors. Too much of the lending was wasteful and inefficient, sustaining donors' own bureaucracies and financing purchases of their own goods and use of their own high-cost consultants. Worst of all, much was politically motivated, incurred in dubious situations that call its legitimacy into question. Should countries be expected to service such debt? Does elementary justice not demand that it be cancelled?

The structure of the enhanced HIPC initiative responds more directly to this set of critics -- it is bigger (more costly for donors), and faster than previous debt relief efforts - yet they level three central critiques:

A first criticism is that the basic criterion for HIPC eligibility - a country's stock of debt as a share of its exports - is inappropriate (Eurodad 2001a,b). ${ }^{12}$ The criticism is that this ratio is not really germane to whether a debtor country can afford to divert resources away from key social expenditures in order to service outstanding debt. ${ }^{13}$ An alternative approach is to calculate the maximum affordable level of debt service and use that to calculate what percentage of the debt stock needs to be cancelled, rather than decide to cancel a part of the stock of debt based on a comparison with exports.

Second is that HIPC needs a truth-in-accounting lesson. Forgiving unpayable debts is simply accepting reality, not doing the debtors a favor (Roodman 2000). Daniel Cohen (2000) has used a model estimated on data from the Latin American debtor countries to infer what HIPCs'

a group of 39 regional networks in 15 African countries argued that the PRSP is simply "window dressing" (Ranis and Stewart, 2001). Further, the long list of hoops that countries need to jump through in order to have a PRSP approved by the World Bank and IMF (and thus receive the proceeds of debt relief) has forced countries to sacrifice a participatory approach in the face of time constraints.

${ }^{10}$ Addison and Rahman, 2001; Burnside and Fanizza, 2001.

${ }^{11}$ This argument is represented by Sachs et.al. (1999); Jubilee Plus (2001); and Oxfam (2001).

${ }^{12}$ The specific 150 percent benchmark used is also essentially arbitrary, being based on no more than a rule of thumb. The rule of thumb is based on a certain empirical regularity: the finding that defaults become much more common when debt/export ratios exceed something like 200 percent. But that empirical regularity is based on the experience of a different group of countries, most of which were much richer than the HIPCs.

${ }^{13}$ Limiting such diversions was proclaimed to be an underlying purpose of the HIPC initiative: that is reflected in the conditionality attached to HIPC, which is designed to ensure that the freed resources are indeed used for social programs and for other investments most likely to reduce poverty. 
debts would be worth in a secondary market, if the donors hadn't continued to lend defensively to help cover debt service. He finds that some 90 percent of the debt reduction ought to be counted as a loss (bad debt), and only the remaining 10 percent as ODA. Other comparisons suggest a figure in the same ball-park. ${ }^{14}$ These calculations imply that deeper debt relief, to the point where it accepts the reality of what the debt is really worth, would not actually cost the donors anything much.

A third critique relates to the debt sustainability analyses that the World Bank/IMF team has been conducting in order to decide whether HIPC debt relief is enough to make the countries' debt burdens sustainable. These are projection exercises, designed to test whether the proposed debt reductions are large enough to enable countries to keep their debt/export ratios below 150 percent in the longer term (interpreted as out to the year 2017). Projections from 2001 have been harshly criticized as overly-optimistic, defying both reality and the past performance of HIPC countries (Birdsall and Deese 2002, Eurodad 2001a, Jubilee Plus 2001, Culpepper 2001).

For example, Uganda and Ethiopia are projected to grow at 6 percent a year for the next decade. That is a record achieved in the past by only a few countries like South Korea, Singapore and Ireland. In Africa, the rate has been more like 1 percent. The projections assume increases in the prices of primary commodities on which these countries depend. Yet in the last two decades, the trend in world prices for agricultural and natural resources has been at best erratic and at worst, consistently down. Moreover, the projections ignore the poorest countries' vulnerability to drought and floods. A three-year drought has contributed to the collapse of agriculture in southern Africa this year (though so have civil conflict and political instability).

This matters because many of the efficiency gains for countries from debt relief (explained in the previous section) rely on a predictably manageable stock of debt over the medium term. If a HIPC country receives relief and then immediately falls back into a state of overindebetness because of an exogenous shock, much of the potential benefit of that debt relief is lost.

\section{$\underline{\text { Review of Proposals }}$}

In light of these criticisms, many alternatives or additions to the HIPC framework have been proposed. Among some of them are:

- One hundred percent write-off for all HIPC countries. Some Jubilee debt campaigners and scholars have argued that the donors should completely forgive the debts owed to them by HIPC countries. Indeed, the notion of the Millennial Jubilee embodies this principle. ${ }^{15} \mathrm{~A}$

\footnotetext{
${ }^{14}$ For example, in the 1980s the commercial bank debt of Bolivia (now a HIPC) was quoted at under 10 cents on the dollar prior to the Brady Plan. And the US government, which is mandated by Congress to estimate the present value of its loan portfolio and expense reductions in value as they occur, applies a 92 percent discount to its HIPC debt (GAO 2000).

${ }^{15}$ A recent proposal by Jeff Sachs proposes that all post-HIPC debts be immediately converted into grant aid to address the HIV/AIDS crisis. Sachs argues that there is no financial justification for keeping the remaining debt servicing obligations on these impoverished countries and that the few billion dollars per year in remaining debt service should be re-channeled as grants into urgent social needs.
} 
complete write-off for the 26 decision point HIPC countries would cost an estimated $\$ 27$ billion in net present value (NPV) terms. ${ }^{16}$

But when considering a complete write-off, one must ask the question of whether that debt relief will be additional to current aid, and if not, which other developing countries will pay. Most of the remaining debt held by HIPC countries is owed to multilateral creditors, since most bilateral creditors have already cancelled 100 percent of the debt owed to them. Unless bilateral donors are willing to reimburse the multilateral creditors (with completely additional money) for the lost debt service as a result of 100 percent cancellation of the remaining multilateral debt, other poor countries are likely to end up footing the bill.

Consider the case of the World Bank's International Development Agency (IDA). How would the World Bank group adjust if IDA's HIPC assets were to be wiped out? ${ }^{17}$ Drop the Debt argues that this would not involve the Bank sacrificing its triple-A credit rating. This may be true but is nonetheless misleading in that one would still have to expect its borrowing costs to rise. If the World Bank's reserves are in fact higher than optimal, then the Bank should certainly contribute more of its profits and use less of them to accumulate reserves, but the World Bank is likely incapable of making more than a marginal additional contribution. ${ }^{18}$ It would therefore be necessary to either:

- $\quad$ raise charges to the World Bank’s regular borrowers;

- reduce future lending to IDA countries to match the reduced reflow of IDA funds; or

- invest World Bank funds in income-earning assets and use the interest earned to make grants to poor countries (Meltzer Commission and Lerrick).

The first would make it more expensive to borrow from the Bank, so the burden would fall on such borrowers, which means primarily the middle-income developing countries but also relatively low-income countries such as China and Indonesia. It would be possible to make this cost transitional by rebuilding the Bank's reserves over time, but that would imply either cutting back the Bank's lending or else adding further to the cost of borrowing. In either event it is the Bank's regular borrowers who would pay. The idea that the World Bank (let alone any of the other development banks) sits on a heap of functionless cash is just wrong.

The second approach requires that other IDA borrowers bear the cost of forgiving HIPC debts. It is true that the fall in lending would be exactly equal to the reduction in amortization payments

\footnotetext{
${ }^{16}$ This figure includes $\$ 5$ billion in additional bilateral relief that has already been committed. NPV of debt equals the sum of all future debt-service obligations (interest and principal) on existing debt, discounted at the market interest rate. Since much of the debt of HIPC countries was contracted on concessional (below market) interest rates, NPV is a more appropriate measure of the burden that a country's debt stock imposes.

${ }^{17}$ For the partial write-off under enhanced HIPC, the approach incorporated in present plans is to draw on a trust fund, which is partially funded by donors and partially by contributions from World Bank profits (the latter already a slight tax on non-HIPC borrowers). But even now donor contributions to the trust fund are not adequate to finance fully the enhanced HIPC initiative (the money presently in the trust fund will only last until 2005), let alone full debt cancellation. 
due from the HIPCs, so that there would be no collective benefit or cost to IDA's clients. ${ }^{19}$ But while there would be no cost to IDA borrowers taken collectively, one again needs to ask whether there would be distribution effects. Suppose the Bank arranged for its IDA lending to each borrowing country to contract by the amount of the country's reduced repayment obligations? That would imply reduced new grants or lending to HIPC countries, and would provoke furious criticism that it was deliberately denying countries the benefits of debt relief. ${ }^{20}$ Otherwise, the presumption has to be that loans to non-HIPC IDA borrowers would contract. But that means IDA-only borrowers like Bangladesh and blend borrowers like India and Indonesia would be the ones paying for HIPC!. Given that IDA has based its lending quite consciously to take into accont countries' needs given their poverty levels, ${ }^{21}$ there is a strong likelihood that such a redistribution would have a perverse effect on the global fight against poverty.

The Meltzer-Lerrick plan is to have reflows into IDA invested in income-earning assets, and then use the income generated to make grants. The disadvantage of this is that, unless IDA reflows were to be supplemented by large additional donor contributions, the initial impact would be a severe reduction in the flow of IDA money. (If the assets in which IDA invested yielded 7 percent, then the flow would initially decline by 93 percent in the absence of additional donor funding.)

The African Development Bank is even less able to write off the debts it is owed without undermining its financial position than is the World Bank. ${ }^{22}$ The cost of the HIPC initiative (in NPV terms) represents 102 percent of the AfDB's reserves and loan loss provisions. Comparable figures are 23 percent for the World Bank, 13 percent for the InterAmerican Development Bank, and 20 percent for the IMF. Financing the HIPC initiative is even more problematic for some of the small sub-regional development banks (see Box on CABEI).

There are two morals to this discussion. The first is that additionality matters. The second is that it is wrong to think of the multilateral banks' reserves as 'additional'. Raiding reserves to forgive HIPC debt would come at the expense of other developing countries, perhaps ones that are equally poor and that have been making better headway in combating poverty. The result could well be a reduction rather than an increase in the rate at which global poverty declines and a further threat to achievement of the Millennium development goals.

- Change the ratio for calculating debt relief. Oxfam (2001) proposed that no low-income country should be expected to spend more than 10 percent of government revenue on debt service. This proposal responded to the criticism that a country's debt-to-export ratio was an ill-suited measure to address the needs and constraints of poor countries. This idea forms the foundation for a proposal that is currently being considered by the US Congress. The Debt Relief Enhancement

\footnotetext{
19 The reduction in amortization payments seems to have been overlooked by World Bank spokesmen who have sometimes argued that IDA's inability to maintain the same level of new lending would be damaging collectively to the countries that borrow from IDA.

${ }^{20}$ One could expect many more comments like: "In an almost cynical game of bait and switch, countries like Mozambique have seen the benefits of debt relief canceled out by corresponding reductions in aid, resulting in no net gain for social development activities in the national budget.” Edmund Cain, "Helping poor nations lifts all boats”, Atlanta Constitution, 23 August 2001.

${ }^{21}$ As in the framework that Burnside and Dollar outline (2000).

22 To the extent that the debt is uncollectable, one should say that its financial position has been even more eroded than that of the World Bank, and hence the question of whether it should be recapitalized is even more critical.
} 
Act of 2002 (DREA) which has been introduced in both the US House and Senate, would establish an additional revenue-based criterion for debt relief -- limiting HIPCs' debt service to 10\% of revenue or to $5 \%$ in cases where a "Public Health Crisis" exists as defined by a high HIV/AIDS infection rate. ${ }^{23}$ The new criterion would result in a total of more than $\$ 1$ billion in additional annual debt service relief.

We agree with the spirit though not the letter of this proposal. It makes more sense to link debt relief to needs than exports. However, the difficulty that with a revenue-based debt relief criteria is the incentive that it gives a government to limit its search for tax revenue. Under the proposed legislation (which embodies the Oxfam formula), 10 percent of any extra tax revenue is immediately siphoned off for debt service. Perhaps 10 percent is not a high enough figure to generate a severe disincentive effect, but it is hard to be sure. And even if there is no disincentive effect, there is surely an equity effect: a country is rewarded for having failed to collect enough taxes to pay for a decent level of social expenditures. ${ }^{24}$

The basic problem with the revenue based approach is that the likelihood that it would divert funding away from other low income countries toward the HIPCs irrespective of the relative quality of countries' tax effort and spending allocations. This is much more than a hypothetical danger. The increasing dependence on aid of the heavily indebted poor countries, primarily in Africa, has played a role in reducing aid to India, from 1.5 percent of its GNP a decade ago to as little as 0.1 percent currently, despite the fact that India's tax and spending programs are relatively reasonable and its record in reducing poverty much better than that of most of the HIPCs. Below we refer to what we see as a more efficient though perhaps less politically appealing formula that is needs-based.

\section{A Three-Pronged Solution: Deepen, Widen, and Insure}

In our book, Delivering on Debt Relief we detail a three-pronged proposal to improve the enhanced HIPC initiative. In this paper we will briefly mention the first two components and then expand on the third, which has become more clearly necessary (and politically and practically feasible) in recent months.

Deepen debt relief - It is clear that HIPC countries need more resources for basic education, health - particularly the AIDS crisis - and infrastructure investments to lift them out of poverty. There is political momentum to do more in this group of countries -- mainly small

\footnotetext{
${ }^{23}$ The term "Public Health Crisis" has been defined as a nation in which 5\% of women at prenatal clinics or 20\% of individuals in groups with high-risk behavior, test positive for HIV/AIDS according to data compiled by the Joint United Nations Program on HIV/AIDS

${ }^{24}$ An even more profound departure from the current approach has been urged by Eurodad, in arguing for a countryby-country analysis of how much debt each country can afford to carry without preempting resources available for spending on a basic level of social service delivery. One curiosity is that the country that would get the largest increase in grant aid is Niger, which is a rather small country of about 10 million people but nevertheless is awarded almost a quarter billion dollars of extra grant aid. This is not because Eurodad projects its social expenditure needs to be particularly high: the figure is actually slightly below their average for per capita expenditure needs. Rather, Niger is an outlier because it raises less tax revenue as a percentage of GDP (only 10.2 percent) than any other HIPC. Does one really want to reward countries for failing to get their citizens to pay a reasonable level of taxation?
} 
African countries highly dependent on primary commodities and most affected by AIDS. Additional debt relief is a sensible mechanism to transfer additional resources.

We agree with Oxfam, the sponsors if the DREA, and others that additional debt reduction should be based on the relation between a country's debt payments (or service) and its social and other needs (e.g. to escape a poverty trap). Since using a country's tax revenue in the denominator builds in a potentially unhealthy incentive structure, we recommend a formula that keys the debt service ceiling directly to the level of GNP. That is one variable that no government is going to suppress in order to minimize its debt service bill, and which provides the best single estimate of the ability to afford social services.

Most HIPCs in 1999 collected about 20 percent of their GNP in tax revenue, and a reasonable proportion of revenue to spend on debt service is 10 percent; 10 percent of 20 percent implies spending 2 percent of GNP on debt service. That 2 percent is sustainable, in the sense that it does not require unusual sacrifices by citizens.

The proposal is not very different from the DREA in terms of cost. It would relieve an additional \$700 million of debt service in 2003 for key development needs in 11 HIPCs that are not already at 2 percent debt service to GNP ratio. The 2 percent threshold could be revisited in the context of the DREA and other initiatives, but the logic of using a debt service-to-GNP as the criteria for additional debt relief should be employed.

Widen eligibility to include other low-income countries - Some very poor countries with substantial official debt burdens are not eligible for the HIPC initiative- for the odd reason that they have (or had) good enough credit to gain some access to private capital markets. The official debt of Indonesia, Nigeria, Pakistan, and another 16 poor countries is undermining their ability to get back on a growth track. If and when they meet the conditions of an IMF program, reducing their debt stock to a sustainable level would cost between about $\$ 20$ billion and $\$ 70$ billion, depending on whether Indonesia is included.

Including these countries in a debt relief initiative would dramatically increase the cost to donors. It also brings up the difficult question of selectivity. Making a country like Nigeria eligible for debt relief contingent on an IMF program may release significant resources to the Nigerian government before it is clear that they are able or willing to use those resources for the benefit of its citizens. Including the large poor countries in a debt relief initiative could bring the benefits to hundreds of millions more poor people, but could also undermine the positive institutional changes that HIPC and the PRSP are meant to catalyze.

This tension exists in the current HIPC framework, as pressure from activists to expedite the process of getting countries to decision point has diluted the standard (e.g. to the extent that the Democratic Republic of Congo may soon reach decision point). The original HIPC goal embodied selectivity, expecting that significant measurable progress be made before decision point (and, of course, additional progress between decision and completion points). The process has now slid more toward traditional conditionality, granting decision point contingent on reforms to be undertaken in the future. DRC is still in arrears to all its major creditors, despite recent action by 
the IMF, World Bank, and AfDB to help clear them. With a projected decision point of January 2003, a component of interim HIPC relief to DRC will be used to pay off remaining arrears.

Insure HIPCs against external shocks - In Delivering on Debt Relief, we suggested that low-income countries' vulnerability to shocks in weather and export prices could be addressed by granting additional relief whenever shocks that are clearly exogenous to the country result in a new erosion of debt sustainability. This proposal was meant to address not only poor countries unique vulnerabilities, but also the tendency of the World Bank and IMF to choose optimism over reality when conducting HIPC debt sustainability analyses.

A program that offers adequate insurance to HIPC countries that their debt sustainability will not be undermined by clearly exogenous circumstances is the key to capturing the many benefits of debt relief outlined in the first section of this paper. Private sector investment, the ultimate key to poverty reduction and growth, is wary of the multiple risks of investing in HIPC economies. If enlightened leaders, in coordination with legislatures and civil society, hold up their side of the compact - adhering to the priorities of the PRSP, attacking corruption, and building strong institutions - then it is in the global community's interest to insure that these countries maintain a sustainable debt profile to catalyze growth.

This concept has become more important as new data for countries currently within the HIPC framework has become available. The IMF recently reported that as many as half the countries receiving debt relief will be thrown back into an unsustainable debt situation by next year. Of the four countries already to reach completion point, two - Uganda and Bolivia are projected to have debt-to-export levels above $150 \%$ in 2003. In most cases, the increases in the debt indicators were the result of less than predicted export growth, due to the global economic slowdown and the continued decline of a number primary commodity prices. New borrowing does not seem to have contributed to the ballooning debt-to-export ratios.

Given this new outlook, one might assume that the projections for future performance would have been revised downward, thus highlighting the need for deeper relief to ensure ongoing debt sustainability. What we see in the IMF report instead, are revised projections that still assume an average of almost 6 percent GDP growth rate, an early "recovery" to that high rate, and greater optimism about primary commodity prices, despite the bleak outcome in 2001-2002 (see chart). 


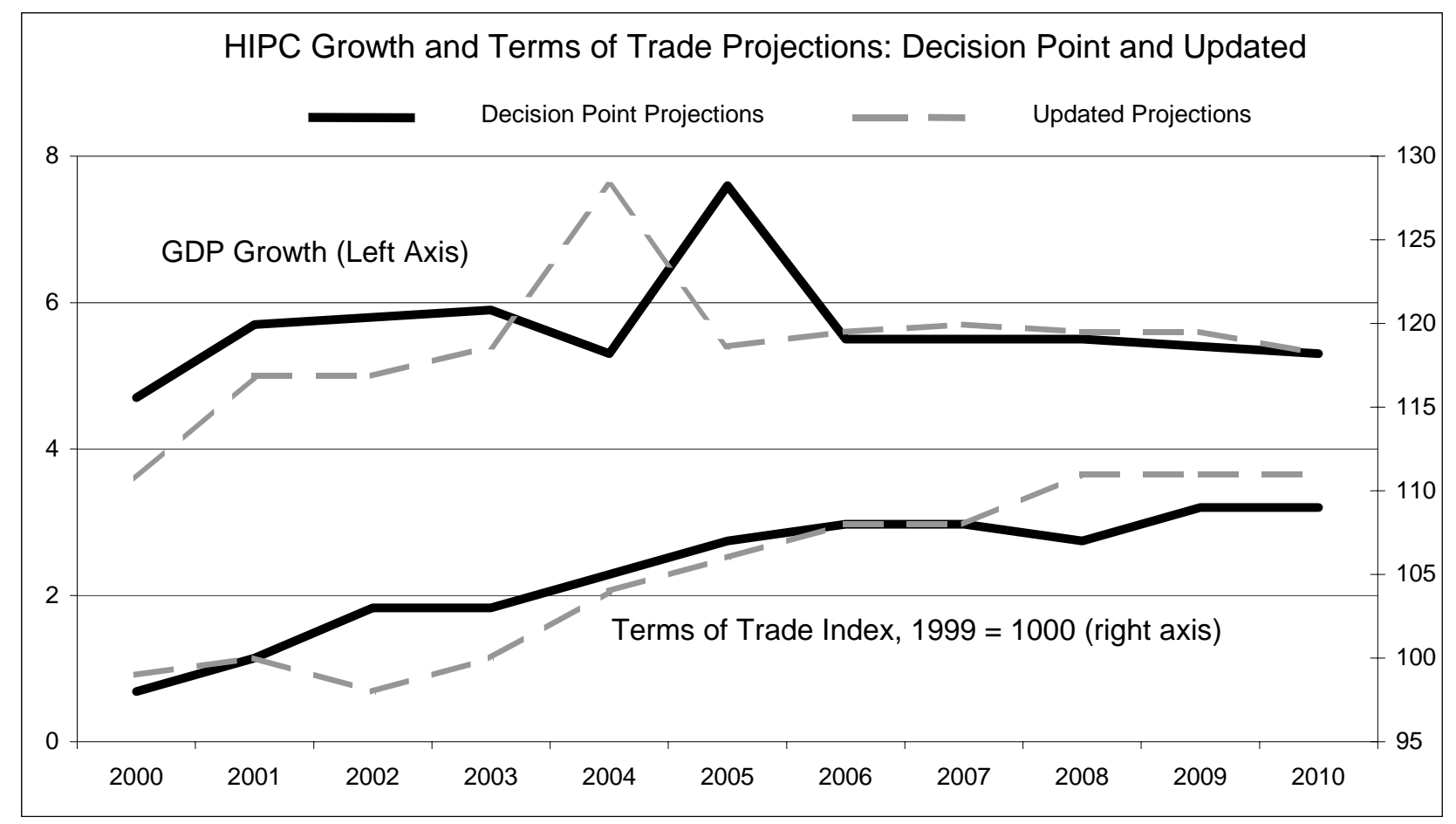

Source: IMF, 2002.

The current enhanced HIPC initiative has built in mechanisms to address the issue of exogenous shocks, but they fall short in three critical ways:

- Time horizon. The HIPC framework does allow a procedure whereby a new debt sustainability analysis is conducted at the completion point and a country that has suffered a severe exogenous deterioration in its circumstances between decision and completion points might be entitled to additional relief (World Bank and IMF 2001b). This procedure, known as 'topping-up,' provides some measure of insurance for HIPC countries for the period between decision and completion points. ${ }^{25}$ That interim period, originally envisaged to average three years, has now been condensed to less than 18 months. As mentioned above, ensuring an adequate period of predictably sustainable debt is a critical component of the success of debt relief in catalyzing poverty reduction and growth. Reasonable people can argue about what length of time is 'adequate' (we suggest 10 years as explained below) but it is clear that the 'topping up' mechanism does not achieve this objective.

The case of Uganda illustrates this point. Uganda was the first country to qualify for debt relief under the original HIPC initiative, and the first to reach enhanced HIPC completion point, in May 2000. Often considered the HIPC poster child, Uganda's successful national dialogue on poverty reduction in the 1990s was one of the models in designing the PRSP. But in 2002, Uganda's debt is projected to rise to 254 percent of exports, well above its 1999 levels and more than double the projected level of 117 percent. The culprit? Not economic mismanagement but a

\footnotetext{
${ }^{25}$ The first case of topping-up occurred in April 2002 when Burkina Faso was granted an additional \$128 million at completion point.
} 
secular decline in world coffee prices, due primarily to Vietnam's entrance into the world market. To quote the recent IMF report, "while the importance of ensuring adequate adjustments in domestic policies in the face of external shocks cannot be overstated, it is equally important to complement such policies with external support, including adequate funds to help deal with cashflow problems arising from exogenous shocks." We agree. But there is no reason why this virtue should not apply to Uganda over the medium term, solely because they were successful in jumping too early through the HIPC loops.

- Burden of proof. While the granting of additional assistance to Burkina Faso at completion point was a welcome signal that 'topping-up' was more than lip-service, there is still considerable uncertainty as to when and under what circumstances the IMF will agree to grant additional resources. The criteria as stated in the IMF paper of 2001 addressing this issue are "a fundamental change in a country's economic circumstances...clearly due to an exogenous development." But the paper emphasizes that topping up is reserved for "exceptional” circumstances, and that part of the reason for changing the criterion from 200 to 150 percent debtto-GDP was to give countries a cushion that would make topping up unnecessary. The comprehensive assessment undertaken to identify fundamental change and exogenous factors is based on IMF and World Bank projections (already shown to be over-optimistic) and require demonstrating that the disruption will be felt for a minimum of 3-5 years. While we certainly want to avoid creating moral hazard with an insurance facility that is too generous, the current system hardly provides the kind of predictability and certainty necessary to reassure potential investors of minimal debt sustainability in HIPC countries.

- Perverse incentives? By limiting access to additional funds to the period between decision and completion points, the HIPC framework may compel interim countries and those yet to reach decision point to delay their completion date and increase their interim borrowing, in an attempt to squeeze all the benefits out of the HIPC initiative before they are thrown to the wolves. Indeed, we have already seen over-borrowing (beyond what was projected) in Ghana, Ethiopia, Benin and Honduras in the interim period.

A more predictable and sustainable insurance facility for HIPC countries’ debt would address these shortcomings. The facility would need to cover a substantial period into the future, at least a decade ${ }^{26}$, if it were to serve the role of reassuring investors that the public sector's debt burden is sustainable. Each year the IMF would calculate whether each HIPC's debt/export ratio exceeded the $2 \%$ of GNP proposed above. If it did, then it would examine whether the excess (or how much of the excess) could be attributed to shocks to the terms of trade, bad weather, or other factors that could reasonably be considered exogenous, as compared to a more realistic set of baseline projections. The IMF would make this calculus available for public scrutiny, and provide enough money to reduce the debts back to a sustainable level.

How much would such a facility cost? It is, of course, impossible to cost such a facility ex ante, since the outlay will depend upon the particular size and sequence of shocks to which the countries are subjected. Nevertheless, the cost of topping-up in 2003 for the current decision point HIPCs - estimated at \$500 million - gives some idea of what the actual cost would be, admittedly

26 But probably it ought not to cover much more than a decade, so as not to create moral hazard by destroying a country's incentive to diversify its economy to reduce its vulnerability to exogenous shocks. 
during a world recession that has weakened commodity prices. Thus $\$ 5$ billion would be a pessimistic estimate of the cost for these 26 countries over ten years. Considering that 10 of the remaining 12 HIPC eligible countries yet to reach decision point are highly dependent on commodity exports, a cost of $\$ 5$ billion for the entire set of HIPCs over ten years is optimistic. ${ }^{27}$

Another way to get a sense of the hypothetical cost of such a contingency facility is to suppose that the value of each HIPC's exports for the next decade rose only at the same rate as in the 1990s (or remained flat, for countries whose exports declined in the past). Suppose also that this occurred because of much less favorable developments in the terms of trade than were assumed in the World Bank/IMF study, which would qualify as an exogenous development. Our calculation as to how much this would cost is shown in the table below, where it can be seen that the cost would be some $\$ 5.2$ billion for the 24 countries that had reached decision point by March 2002. Of course, it is not likely that all countries would end up mirroring the experience of the 1990s - perhaps equally unlikely as them achieving 8.2 percent annual export growth -- but the estimate again suggests that $\$ 5$ billion may be an optimistic figure for the cost of such a procedure for al HIPCs.

And it would cost nothing at all if the IMF and World Bank's rosy projections prove right for every country!

Such contingent facilities are not completely new to the international system. The IMF has for many years operated a Contingency Financing Facility that lends (though it does not grant) money to IMF member countries experiencing a shortfall in export proceeds due to circumstances outside their control. Similarly, the Mexican bonds issued under the Brady Plan included contingent payments to their holders that allowed them to benefit if the price of Mexican oil exports exceeded a benchmark level.

\section{Financing}

In this section, we focus on the financing mechanisms for the insurance facility. In Delivering on Debt Relief we propose ways to finance both the deepening and expanding of a HIPC-style debt reduction program. In the time since publication, more bilateral creditors have moved to 100 percent cancellation of debt owed to them by HIPC countries, which has lowered the potential cost of deepening. For example, the DREA to bring HIPC countries to the 10 and 5 percent of debt service to revenue levels would only cost the US \$43 million in 2003. The issue of debt in HIPC countries - and thus additional debt reduction - is increasingly becoming a multilateral debt issue. On the issue of expansion, the cost has made serious consideration politically infeasible, although some US congressmen have expressed interest in taking up the issue in subsequent years.

To finance the insurance facility for HIPC country debt, we propose tapping an important under valued resurce that belongs to the world community - IMF gold. The IMF currently has substantial holdings of gold on its books that are valued at the old official price of SDR 35 per ounce (currently about \$45), compared to the market price of about \$290 per ounce. In 1999, it mobilized 14 of the Fund's 103 million ounces of gold, the interest from which helped finance the

\footnotetext{
${ }^{27}$ The extra countries that we are suggesting adding are mostly much less vulnerable to commodity shocks.
} 
IMF's portion of HIPC. At the current price, this would yield something over $\$ 20$ billion if the whole of the Fund's undervalued gold were to be mobilized.

Since gold has long since ceased to serve any serious monetary function, IMF gold could be used to pay for the annual cost of the HIPC insurance facility. It is true that this would amount to reducing the IMF's reserves, but, unlike the multilateral development banks, the IMF does not need a reserve to reassure lenders and thus permit it to borrow cheaply. The only function of the IMF gold stock is to reassure central bankers that their funds are safe with the IMF. ${ }^{28}$ We believe that the needs of the HIPCs and other poor countries are many times more compelling than safeguarding against the contingency of central bank irrationality.

Some would argue that despite the possible resistance in the U.S. Congress to IMF gold sales (or the complication that the Congress would insist on other reforms at the IMF in exchange for its approval), gold sales are all too easy and cheap an escape for the donors. We do not think this logic warrants rejecting gold sales altogether. Debt relief (and new transfers) have large potential benefits for reducing poverty, especially if the amount of relief is predictably sustained. This is true even if an insurance facility does not appear to "cost” the traditional donors anything.

\footnotetext{
${ }^{28}$ The IMF thinks that holding a lot of undervalued gold "provides fundamental strength to [its] balance sheet” and "provides the IMF operational maneuverability" (www.imf.org/external/np/exr/facts/gold.htm) More specifically, the Fund argues that its gold holdings matter in allowing even conservative central bankers to treat quota increases as an asset swap rather than a donation, since they know that if necessary the Fund could sell some gold to keep its balance sheet whole if some of its loans to distressed debtors were to sour. While the Fund does indeed lend to countries with major macro problems, its record in recovering debts on its own balance sheet (as opposed to that of the PRGF, which has a separate balance sheet) is sufficiently sound to make it perfectly sensible for its members to treat quota increases as asset swaps, with or without the Fund's extra "gold” security.
} 


\section{References}

Addison, Tony and Aminur Rahman. 2001. "Resolving the HIPC Problem: Is Good Policy Enough?”, paper presented at the WIDER Conference on Deb, Helsinki, August.

Birdsall, Nancy, Stijn Claessens and Isaac Diwan. 2001. Will HIPC Matter? The Debt Game and Donor Behavior. Carnegie Endowment for International Peace Economic Reform Project Discussion Paper (No. 3, March).

Birdsall, Nancy and John Williamson, with Brian Deese. (2002). Delivering on Debt Relief: From IMF Gold to a New Aid Architecture. Washington D.C., Institute for International Economics/Center for Global Development.

Birdsall, Nancy and Brian Deese. (2002). “What Ever Happened to Debt Relief for Africa?” International Herald Tribune, June 27.

Burnside,Craig and David Dollar, (2000), "Aid, Policies, and Growth", American Economic Review, Sep. 90(4).

Burnside, Craig and Domenico Fanizza, (2001), “Hiccups for HIPCs”, paper presented at the WIDER Conference on Deb, Helsinki, August.

Chinnock, Jeffery. (1998) “In Whose Benefit? The Case for Untying Aid.” ActionAid.

Cohen, Daniel (2000), The HIPC Initiative: True and False Promises, Working Paper (Paris: OECD Development Centre).

Culpepper, Roy, and John Serieux, (2001), Journeys Just Begun: From Debt Relief to Poverty Reduction. (Ottawa: North-South Institute).

Drop the Debt (2001), "Reality Check: The Need for Deeper Debt Cancellation and the Fight Against HIV/AIDS” (Washington: Drop the Debt).

Easterly, William (1999), How did highly indebted poor countries become highly indebted? Reviewing two decades of debt relief(World Bank).

Eurodad (2001a), “Rethinking HIPC Debt Sustainability”, at http://www.eurodad.org/ . (2001b), “Putting Poverty Reduction First”, at http://www.eurodad.org/.

General Accounting Office (2000), Debt Relief Initiative for Poor Countries Faces Challenges (Washington: United States General Accounting Office).

International Monetary Fund. (2002). The Enhanced HIPC Initiative and the Achievement of Long-Term External Debt Sustainability. at http://www.worldbank.org/hipc/Long-Term.pdf 
Jubilee Plus (2001), “HIPC: Flogging a Dead Process” (London: Jubilee Plus).

Kremer, Michael, and Seema Jayachandran (2001), “Odious Debt,” unpublished draft.

Lerrick, Adam (2000), "HIPC: The initiative is lacking," Euromoney, (IMF/World Bank Issue).

International Financial Institutions Advisory Commission (Meltzer Commission) (2000), "Report to the US Congress” at http://www.house.gov/jec/imf/ifiac.htm.

Oxfam (2001), “Debt Relief: Still Failing the Poor” Oxfam International.

Pettifor, Ann, Thomas, Bronwen \& Telatin, Michela. (2001) “HIPC - Flogging a Dead Process” Jubilee Plus.

Ranis, Gustav, and Frances Stewart. "The Debt-Relief Initiative for Poor Countries: Good news for the poor?” Paper presented at the WIDER Conference on Debt, (Helsinki, August).

Roodman, David (2001), Still Waiting for the Jubilee: Pragmatic Solutions for the Third World Debt Crisis (Washington: Worldwatch Institute).

Sachs, Jeffrey, Kwesi Botchway, Maciej Cuchra, and Sara Sievers, (1999) "Implementing Debt Relief for the HIPCs.” Center for International Development Working Paper.

Thomas, Melissa, (2001). “Getting Debt Relief Right,” Foreign Affairs, (September/October).

World Bank and IMF (2001a), “The Challenge of Maintaining Long-Term Debt Sustainability”, at www.imf.org/external/np/hipc/2001/lt/042001,htm.

(2001b), “Enhanced HIPC Initiative—Completion Point Considerations”, mimeo, August 17. (2001a), “Financial Impact of the HIPC Initiative: First 23 Country Cases”, www.worldbank.org/hipc. (2001b), Global Development Finance (Washington: World Bank). 


\section{BOXES:}

\section{1: Debt Initiatives}

- 1987: Special Program of Assistance for Africa. Informal donor association managed by the World Bank to provide bilateral debt relief, IDA credits for IBRD debt service relief, and funding for commercial debt buybacks. Available to African IDAonly borrowers with debt service-to-exports above $30 \%$ (initially 21 countries).

- 1988: Paris Club: Toronto Terms. First agreement by Paris Club creditors to implement new treatment on the debt of lowincome countries. The level of reduction was defined as $33.33 \%.){ }^{29}$

- 1989: Brady Plan. World Bank and IMF facilitated debt and debt service reductions by commercial bank creditors. Most Brady deals went to middle-income countries.

- 1989: IDA Debt Reduction Facility. Established to restructure and buy back commercial debt with IDA credits (average $88 \%$ discount). Available to low-income countries (heavily indebted IDA-only borrowers). Funded from IBRD net income transfer.

- 1990: Paris Club: Houston Terms. Agreement to implement a new treatment of the debt of the lower middle-income countries. Houston terms had three components: repayment periods lengthened to or beyond 15 years and ODA repayment periods lengthened up to 20 years with a maximum of 10-year grace; ODA rescheduled at a concessional rate, and the introduction of bilateral debt swaps.

- 1991: Paris Club: London ("Enhanced Toronto") Terms. Debt service reduced 50\% on non-concessional bilateral debt (12 year grace, 30 year maturity).

- 1995: Paris Club: Naples Terms. Debt service reduced 67\% on non-concessional bilateral debt (16 year grace, 40 year maturity). Option of debt stock cancellation (5 stock deals processed). ${ }^{30}$

- 1996: Heavily Indebted Poor Countries (HIPC) Initiative. Debt stock reduction to bring debt/export ratio under $200 \%$ for 41 heavilyindebted and poor countries. Participation of multilateral creditors.

- 1996: Paris Club: Lyon Terms. Agreement within HIPC framework for $80 \%$ relief on non-concessional bilateral debt for HIPC-eligible countries.

- 1999: Enhanced HIPC (HIPC II) Initiative. Increased stock reductions to bring debt of HIPCs to under $150 \%$ debt-toexports. Interim debt service reduction between decision and completion points. Relief conditioned on the completion of comprehensive Poverty Reduction Strategy Papers (PRSPs).

- 1999: Paris Club: Cologne Terms. Agreement within HIPC framework, where non-ODA credits are cancelled up to a 90\% level or more if necessary in the context of the HIPC initiative (including topping-up). ODA credits are rescheduled at an interest rate at least as favorable as the original concessional interest rate applying to these loans (40 years with 16-year grace and progressive repayment).

\footnotetext{
${ }^{29}$ Paris Club debt reduction decisions are made according to five principles: case-by-case decision-making, consensus, conditionality (the existence and continuation of an IMF program), solidarity, and comparability of treatment.

${ }^{30}$ Option of stock treatments was/is implemented "on a case-by-case basis, for countries having established a satisfactory track record with both the Paris Club and IMF and for which there is sufficient confidence in their ability to respect the debt agreement.” (Paris Club website).
} 


\section{2: CABEI}

The example of the Central American Bank for Economic Integration highlights the distributive challenges of offering debt relief to a limited number of countries. CABEI has been operating in the region since 1960, and is the second largest source of financing for the countries of Central America. In 1999, when the Enhanced HIPC initiative was announced, it became clear that it posed a significant problem for CABEI. Two of CABEI's five members (Honduras and Nicaragua) were eligible for relief. Under the HIPC terms, the burden of debt relief imposed was equivalent to half of CABEI's net worth. For $\mathrm{CABEI}$, financing this effort without help from the international community would have threatened the solvency of the institution. Furthermore, it would have involved a transfer of resources from some poor countries to others, negating the underlying rationale for the HIPC initiative. Thus the leadership of CABEI appealed to the World Bank and the international community for assistance in covering their share of debt reduction in Honduras and Nicaragua. An agreement was reached with the G-7, European Union, World Bank and IMF for more than half of CABEI's share to be paid out of the World Bank HIPC Trust Fund. Nevertheless, CABEI committed significant resources of its own to the HIPC initiative, becoming the first institution to grant debt relief to Honduras (\$252 million) in April 2000 (it subsequently wrote off $\$ 435$ million of Nicaragua's debt.)

Looking to the future, CABEI is constrained in its ability to lend to Honduras and Nicaragua, because under the HIPC arrangement it is not permitted to lend to these countries on non-concessional terms, and it has not traditionally had a fund with resources for concessional loans. CABEI has created a new Special Trust Fund for Social Transformation in Central America to finance loans on concessional terms, but this facility has received only $\$ 9$ million in commitments. 
Table: Hypothetical Cost of Contingency Procedure

\begin{tabular}{|c|c|c|c|c|c|c|c|c|}
\hline & HIPC Export & Projections & Ex. Growth & Revised Export Projections & 2010 Debt Stock & Debt-to-Export Ratio & Stock Goal & Reduction \\
\hline & 2001 & 2010 & 90-99 avg. & 2010 (based on '90s growth) & HIPC Projection & Revised & at $150 \%$ &.. \\
\hline Benin & 392 & 791 & 2.5 & 489 & 795 & 1.63 & 734 & 62 \\
\hline Bolivia & 1442 & 3108 & 3.6 & 2054 & 3333 & 1.62 & 3081 & 252 \\
\hline Burkina Faso & 305 & 751 & -2.6 & 305 & 1024 & 3.36 & 458 & 567 \\
\hline Cameroon & 2586 & 4248 & 0.0 & 2586 & 4248 & 1.64 & 3879 & 369 \\
\hline Chad & 242 & 1978 & 0.6 & 255 & 934 & 3.66 & 383 & 552 \\
\hline Ethiopia & 952 & 1815 & 2.6 & 1199 & 2439 & 2.03 & 1799 & 641 \\
\hline The Gambia & 128 & 233 & 2.7 & 163 & 301 & 1.85 & 245 & 57 \\
\hline Ghana & 2416 & 4597 & 11.1 & 6180 & 3503 & 0.57 & .. & .. \\
\hline Guinea & 860 & 1647 & -1.0 & 860 & 1565 & 1.82 & 1290 & 275 \\
\hline Guinea-Bissau & 71 & 181 & 7.5 & 136 & 248 & 1.82 & 204 & 44 \\
\hline Guyana & 718 & 1037 & 5.0 & 1114 & 736 & 0.66 & .. & .. \\
\hline Honduras* & 2673 & 5456 & 8.5 & 4361 & 3323 & 0.76 & .. & .. \\
\hline Madagascar & 1046 & 1811 & 6.5 & 1731 & 1929 & 1.11 & .. & .. \\
\hline Malawi & 480 & 763 & 2.1 & 579 & 1148 & 1.98 & 869 & 280 \\
\hline Mali & 662 & 1190 & 2.3 & 812 & 1520 & 1.87 & 1218 & 302 \\
\hline Mauritania** & 433 & 528 & -2.5 & 433 & 656 & 1.52 & 650 & 7 \\
\hline Mozambique & 805 & 3451 & 6.8 & 1455 & 1611 & 1.11 & .. & .. \\
\hline Nicaragua* & 932 & 1570 & 10.0 & 1651 & 1712 & 1.04 & .. & .. \\
\hline Niger & 279 & 484 & -4.5 & 279 & 768 & 2.75 & 419 & 350 \\
\hline Rwanda & 126 & 367 & -3.0 & 126 & 541 & 4.29 & 189 & 352 \\
\hline Sao Tome & 18 & 42 & 5.0 & 28 & 59 & 2.11 & 42 & 17 \\
\hline Senegal & 1692 & 2765 & -1.0 & 1692 & 2364 & 1.40 & .. & .. \\
\hline Sierra Leone & 121 & 330 & -5.0 & 121 & 127 & 1.05 & .. & .. \\
\hline Tanzania* & 1194 & 2274 & 7.9 & 1884 & 3525 & 1.87 & 2826 & 699 \\
\hline Uganda & 801 & 1953 & 11.5 & 2134 & 1320 & 0.62 & .. &.. \\
\hline Zambia & 1038 & 2207 & -3.0 & 1036 & 2575 & 2.49 & 1554 & 1021 \\
\hline Total & & & & & & & w/out Chad & 5292 \\
\hline
\end{tabular}

Note: We exclude Chad from the total because of the likely increases in exports due to exploitation of oil reserves.

*Stock in 2007; ** 2006 



\title{
Appendix: Ten Questions about Debt and Debt Relief
}

\author{
1. How much debt is there, and to whom is it owed?
}

Debt owed by the HIPC countries is about $\$ 170$ billion (in 1999 nominal terms). ${ }^{31}$ Almost $50 \%$ of this is owed to bilateral creditors - mostly the U.S, Japan, France, Britain and other countries of Europe. Another $37 \%$ is owed to multilateral creditors: the World Bank, IMF and the regional and sub-regional development banks; and $13 \%$ to private creditors (of which almost all is backed by a sovereign guarantee).

The debt of the HIPCs represents only 8\% of the developing world's approximate $\$ 2$ trillion debt, and only 35\% of the debt of all the low-income countries (using the World Bank's country classification of "low-income", which includes India, Indonesia, Nigeria, and Pakistan). For the developing world as a whole, about $25 \%$ of debt is owed to bilaterals, $17 \%$ to multilaterals, and the remaining $60 \%$ to private creditors (half of which is not covered by a sovereign guarantee).

2. What portion of the debt stock of the poorest countries would be deemed uncollectable and written off or canceled if conventional accounting practices of commercial banks were followed?

Commercial banks would eventually be required to provision against debt that has lost much of its value. One measure of the value of commercial debt is the price it commands in the market. In the late 1980s, $\$ 1$ of commercial debt of countries like Bolivia and Nicaragua (now HIPCs) was worth as little as 10 cents on the dollar in the market - meaning that the market judged about 90 percent of its value to be uncollectable. Most HIPC debt is owed not to commercial but to official creditors, so there is no such market measure. However, the US government - which is congressionally mandated to estimate the present value of its loan portfolio and expense reduction in values as they occur - applies a 92\% discount to the HIPC debt. On the other hand, in 1999 HIPCs paid about 85 percent of the debt service they were due to pay - but they were only able to do this because of big receipts of new aid.

3. What portion of the debt of the poor (HIPC) countries would be labeled "unjust" or "odious" by reasonable observers?

"Odious" debt has been legally defined as debt assumed by governments without the consent of the people and not for their benefit. Over the past three decades as much as 60 percent of private and public loans were committed by creditors to countries subsequently labeled as not free, or corrupt in the year of the commitment, according to some international indices. In the Congo (former Zaire), Nicaragua, Pakistan and other heavilyindebted poor countries, there were periods when governments borrowed heavily to purchase military equipment of little benefit to ordinary citizens (Nicaragua in the 1970s), to invest in white elephant projects (Pakistan in the 1970s), or to pad the foreign bank accounts of corrupt dictators (Zaire under Mobutu). One approach is to label as odious all debt assumed by "odious" governments - since even borrowing for good projects by odious governments may have simply made it easier to steal or misuse domestic resources. A simple measure of odious or unjust debt might then be all debt assumed by such governments. Unfortunately, labeling and quantifying "odious" debt does not provide much useful guidance on how much to forgive now (for more on the odious debt issue, see Kremer and Jayachandran 2001, and the appendix of Birdsall, Williamson and Deese 2002).

4. Who should be asked to pay for debt relief?

\footnotetext{
${ }^{31}$ The amount of debt is often expressed in net present value (NPV) terms. The NPV takes into account the fact that amounts owed in the future impore less of a burden than an equal amount owed now, for the same face value. The NPV of HIPC countries' current debt is about \$107 billion.
} 
In a conventional bankruptcy proceeding, the creditors are expected to recognize that their assets are worth less than face value, and have them scaled down to what the debtor can afford to pay. . Almost all of the debt of the poorest countries is owed to official, not private commercial creditors. That means that it has been rich country governments that have either loaned directly to poor country governments, or have allowed the World Bank, the IMF, or other institutions that they control to make the now "bad" loans. So when push comes to shove, it is the taxpayers of the rich country governments that are the creditors of the poor country governments, and who thus have to bear the costs of debt relief. Rich country taxpayers basically have to foot the bill, except insofar as they might authorize the IMF to sell some of its gold, unless they choose to shift the burden to other poor countries.

5. What about loans to purchase G-7 goods? How should they be treated in an analysis of debt relief?

The HIPC initiative involves a 90 percent write-off of bilateral debt (Paris Club 'Cologne Terms'), and a number of countries, including the US and UK, have moved unilaterally to completely write-off their bilateral HIPC debts. This means in a sense that the past sins of 'tied aid' are wiped clean. We have argued that one of debt relief's central advantages over additional new aid is the efficiency gain that comes from releasing poor countries from the kind of nonsense involved in aid contracts mandating the purchase of high-priced Western goods and services. The OECD countries have pledged to end the practice of tied aid, but they have not yet applied this pledge to the two most insidious areas: technical cooperation and food aid.

6. How much good would it do the debtor countries if their debt were completely instead of partially written-off? What negative impact would result in the creditor countries?

In 1999, the HIPCs paid about $\$ 8$ billion in debt service on their outstanding stock of debt ( $\$ 170$ billion, nominal). If the debt stock were to be completely eliminated, then would the HIPCs get an immediate $\$ 8$ billion-a-year windfall? We doubt it. Over the past two decades, the HIPCs have continued to receive large positive net transfers of resources -- on the order of $\$ 10$ billion in the second half of the 1990s - over and above their debt service payments. We doubt that the donor governments (who would have to show in their own budgets the "cost" of the unpaid debt) and the multilateral creditors (who would no longer need to make new loans to help countries pay back old loans) would refrain from cutting back, at least somewhat, on new transfers. In fact that seems to have already happened in the late 1990s, when despite higher debt relief, total transfers including debt relief, not only failed to rise, but actually fell. The impact on creditor countries is so tiny in financial terms that it makes no sense to quantify it. And even if the HIPCs got a full $\$ 8$ billion windfall, there would be a question of equity if part of it came at the expense of other poor countries - countries that have made better use of the resources in stimulating development and combating poverty

7. Why is debt a worthwhile focal point when talking about development in poor countries?

While debt relief is just another form of resource transfer to poor countries, there are (as we explain in section 1) some good reasons to favor somewhat more debt relief over new grants or loans. On the other hand, even complete debt relief would be only a small step toward reducing poverty and advancing development, and would be small compared to the potential benefits of better market access. Even with more debt relief, a seriously stepped-up rich country effort to commit new resources is crucial.

8. Are children really dying because of the debt burden imposed on poor countries?

We think it is wrong to assert that. Why? Because the poorest and most indebted countries have generally been receiving much more aid each year than what they pay in debt service. In the worst cases, much of their new aid was needed to pay their debt service - but even then they ended up at least slightly ahead. 
There are, of course, other more fundamental reasons why children are dying, and insufficient resources is one of them

9. Who are the central players in the debt relief debate, and who should the central players be? Who has the voice, and who should have the voice?

The big players in the debate about debt relief have been:

(1) the large donor countries - to whom much of the debt is owed, and who have the most influence in the World Bank and the IMF, the institutions that manage the HIPC program -- and

(2) Nongovernmental activist organizations such as Jubilee, Eurodad and others mentioned in the text (and see the bibliography), based mostly in those rich countries but with local affiliates in many debtor countries.

Group \#1 has been a quiet but powerful player - proceeding with deeper debt relief when it became obvious the shell game of making new grants and loans to finance debtors' debt service was undermining the logic and effectiveness of development assistance, though then only at a pace and on terms they could financially and politically "afford." Group \#2 has created the persistent and healthy pressure on Group \#1 needed to make the process deeper, broader and more transparent.

10. What steps would most advance development in poor countries? Would debt relief even be one of them?

Five steps most critical to reducing poverty and advancing development in today's poor countries are:

a) stable and honest government that commands the assent of the governed;

b) market-oriented economic policies, relying on private investment and entrepreneurship to generate good investments and jobs;

c) a social contract: adequate health, education and other social investments that provide economic and social opportunity for all; and

d) good access to rich country markets; and

e) an additional $\$ 50$ billion a year in development assistance to build the institutions and finance the programs noted above that can help them escape poverty traps.

But those reflect the opinions of the authors; others might choose other steps. 